\title{
Non-canonical NF-кB signaling initiated by BAFF influences B cell biology at multiple junctures
}

\author{
Sandra Gardam ${ }^{1 *}$ and Robert Brink ${ }^{1,2}$ \\ 1 Immunology Division, Garvan Institute of Medical Research, Darlinghurst, NSW, Australia \\ 2 St. Vincent's Clinical School, University of New South Wales, Darlinghurst, NSW, Australia
}

\section{Edited by:}

John Silke, Walter and Eliza Hall

Institute, Australia

\section{Reviewed by:}

Hideki Ogura, Osaka University, Japan Kai Fang, University of California Los Angeles, USA

${ }^{*}$ Correspondence:

Sandra Gardam, Garvan Institute of Medical Research, 384 Victoria Street, Darlinghurst, NSW 2010, Australia e-mail:s.gardam@garvan.org.au

It has been more than a decade since it was recognized that the nuclear factor of kappa light polypeptide gene enhancer in B cells (NF-kB) transcription factor family was activated by two distinct pathways: the canonical pathway involving NF-kB1 and the non-canonical pathway involving NF-kB2. During this time a great deal of evidence has been amassed on the ligands and receptors that activate these pathways, the cytoplasmic adapter molecules involved in transducing the signals from receptors to nucleus, and the resulting physiological outcomes within body tissues. In contrast to NF-kB1 signaling, which can be activated by a wide variety of receptors, the NF-kB2 pathway is typically only activated by a subset of receptor and ligand pairs belonging to the tumor necrosis factor (TNF) family. Amongst these is B cell activating factor of the TNF family (BAFF) and its receptor BAFFR. Whilst BAFF is produced by many cell types throughout the body, BAFFR expression appears to be restricted to the hematopoietic lineage and $B$ cells in particular. For this reason, the main physiological outcomes of BAFF mediated NF-KB2 activation are confined to B cells. Indeed BAFF mediated NF-KB2 signaling contributes to peripheral B cell survival and maturation as well as playing a role in antibody responses and long term maintenance plasma cells. Thus the importance BAFF and NF-kB2 permeates the entire B cell lifespan and impacts on this important component of the immune system in a variety of ways.

\section{Keywords: BAFF, BAFFR, NF-KB2, B lymphocyte, signaling}

\section{INTRODUCTION}

In 2001 it was recognized that nuclear factor of kappa light polypeptide gene enhancer in B cells (NF- $\mathrm{B}$ ) signaling actually consisted of two distinct pathways which have become known as the canonical (classical/NF- $\mathrm{kB} 1$ ) and non-canonical

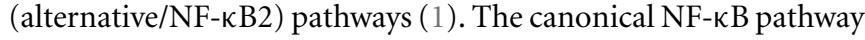
involves the constitutive processing of full length NF- $\mathrm{KB} 1$ (p105) to its active form p50, which readily forms dimers with RelA (also known as p65) or c-Rel. These dimers are retained in the cytoplasm by the actions of the inhibitors of NF- $\kappa B$ (Iк-B proteins), which mask their nuclear translocation signals. Signal-induced activation of this pathway leads to phosphorylation by the Iк-B kinase (IKK) complex (consisting of IKK $\alpha$, IKK $\beta$, and IKK $\gamma$ ) of the IK-B proteins, subsequently leading to their degradation and allowing nuclear translocation of p50 containing dimers [reviewed in Ref. (2)]. In the non-canonical NF- $\kappa B$ pathway, NF- $\kappa B 2$ (p100) acts as the IK-B by retaining itself and RelB in the cytoplasm. Processing of NF- $\mathrm{KB} 2$ to its active form, $\mathrm{p} 52$ only occurs upon signal-induced activation of the pathway (3) and it is the loss of the carboxyterminus of p100, which facilitates translocation of active p52/RelB dimers to the nucleus. In both pathways the presence of NF- $\mathrm{KB}$ dimers in the nucleus initiates specific transcription programs via the binding of dimers to $\mathrm{\kappa B}$ sequences in the promoters of various genes. In this way the NF- $\mathrm{kB}$ signaling pathways are able to exert a variety of effects on tissues throughout the body. Interestingly, the non-canonical NF- $\mathrm{kB}$ pathway appears to activate a relatively small number of downstream genes compared to the canonical pathway (4), with the specific genes activated potentially varying depending on the cell type involved.

The major class of ligand/receptors pairs responsible for activating NF- $\mathrm{\kappa B} 2$ signaling are the receptors of the tumor necrosis factor (TNF) family. Whilst the members of the TNFR superfamily that carry cytoplasmic death domains do not typically trigger non-canonical NF- $k B$ signaling (e.g., TNFR1, Fas), those that lack death domains are invariably found to stimulate this pathway to some degree (5). Non-death domain members of the TNFR superfamily for which strong NF- $\mathrm{\kappa} 2$ activation has been demonstrated include CD40 (also known as TNFRSF5), lymphotoxin beta receptor (LT- $\beta R$ also known as TNFRSF3), receptor activator of NF- $\kappa B$ (RANK also known as TNFRSF11a), and B cell activating factor of the TNF family receptor (BAFFR also known as TNFRSF13c). This review focuses on NF-кB2 activation by BAFFR and its ligand BAFF and the specific outcomes for tissues which express this receptor. The BAFF and BAFFR families of molecules will be described as well as the proximal signaling events which have been linked to this ligand/receptor pair. Finally, given the almost complete confinement of BAFFR expression to $B$ cells, the effects of BAFF/BAFFR induced NF- $\mathrm{KB} 2$ on B cell survival, maturation, and responses will be described.

\section{INTRODUCING THE MAIN PLAYERS \\ THE LIGANDS: BAFF AND APRIL}

B cell activating factor of the TNF family (BAFF, also known as TNFSF13B) was identified simultaneously by several groups in 
1999, who variously named it BAFF, Blys, TALL-1, THANK, and zTNF4 (6-10). BAFF was soon recognized to be a factor essential to the survival of mature, conventional B lymphocytes. Like other members of the TNF ligand family, BAFF is type II transmembrane protein which forms a constitutive trimer. However, it can be readily cleaved by furin to release as a soluble factor. In soluble form BAFF can persist as a trimer or assemble into a 60 mer, consisting of 20 trimers, which maintains receptor binding capabilities and may indeed bind to more than one receptor at a time $(11,12)$. Despite the crystallographic evidence for this multimeric form, little is understood about its functional significance. A splice variant of BAFF has also been identified, $\triangle B A F F$, which opposes the actions of BAFF by sequestering full length BAFF in heteromultimers. Unlike full length BAFF, $\triangle \mathrm{BAFF}$ is confined to the membrane $(13,14)$.

A proliferation inducing ligand (APRIL, also known as TNFSF13) is closely related to BAFF and they share some receptor specificity. Cleavage of APRIL by furin convertase occurs at the Golgi apparatus (15) and soluble trimeric APRIL is subsequently secreted from the cell. As such, membrane bound forms of APRIL are not observed at the cell surface. However a fusion protein formed from trans-splicing of TNF-related weak inducer of apoptosis (TWEAK, also known as TNFSF12) and APRIL, known as TWE-PRIL is membrane bound and displays the APRIL receptor binding domain at the cell surface (16). TWE-PRIL is biologically active, however its physiological role is yet to be identified. Soluble APRIL trimers have been shown to interact via non-receptor interacting sites with cell surface heparin sulfate proteoglycans (HSPG), which is thought to create multimeric forms that are more biologically active than cell-free APRIL trimers (17-19). Heterotrimers of BAFF and APRIL have also been identified (20) and have been shown to be present in the sera of patients with various autoimmune diseases, though their contribution to disease or any physiological function has not yet been elucidated.

Cells of the innate immune system, including neutrophils, macrophages, monocytes, and dendritic cells, are the main producers of BAFF and APRIL. More recently a number of nonhematopoietic cells have been identified which also produce BAFF and/or APRIL, including osteoclasts, some epithelial cells, and astrocytes to name a few. Many of these have been identified at sites of disease and as such may be responsible for maintaining a local $\mathrm{B}$ cell population in response to disease [reviewed in Ref. (21)].

\section{THE RECEPTORS: TACI, BCMA, AND BAFFR}

BAFF and APRIL share binding to two TNFR family members: transmembrane activator and calcium modulator and cyclophilin ligand interactor (TACI, also known as TNFRSF13B) and B cell maturation antigen (BCMA, also known as TNFRSF17). Additionally BAFF, but not APRIL, is also able to interact with a third receptor, BAFFR (TNFRSF13C). However a splice variant of APRIL has been detected in mice which shows some affinity for BAFFR (22). All three receptors display the trimeric structure common to TNFR members and contain TNF receptor associated factor (TRAF) binding sites in their cytoplasmic domains but lack death domains. Amino acid residues in BAFF that are involved in TACI binding have been identified (23), although the extent to which these are also required for binding to BAFFR and
BCMA is yet to be determined. The expression of all three receptors is restricted mainly to B lymphocyte lineage cells. Both BAFFR and TACI are widely expressed on all B cells, with BAFFR levels increasing as the B cells mature. TACI is particularly high on marginal zone (MZ) and B1 B cells in the mouse and $\mathrm{CD} 27^{+}$memory $\mathrm{B}$ cells in humans. BCMA expression is restricted to plasma cells (PCs) in the mouse, though in humans it is also expressed on some germinal center (GC) and memory B cells $(24,25)$. On non-B cells, BAFFR is expressed on activated $\mathrm{T}$ cells and $\mathrm{T}$ regulatory cells (26), whilst TACI is expressed on dendritic cells and monocytes $(27,28)$. However in contrast to their roles in $\mathrm{B}$ cell biology, little is known about their roles in these other cells types.

TACI is able to recruit TRAFs 2, 5, and 6 to its cytoplasmic domain (29) and has been shown to activate NF-кB1, AP-1, and NFAT signaling pathways (30). BCMA has binding sites for TRAFs 1,2 , and 3 in its cytoplasmic tail and is capable of activating NF$\kappa \mathrm{B} 1$, Elk-1, p38 MAPK, and JNK signaling pathways (31). BAFFR contains only a single TRAF binding site, specific for TRAF3 and efficiently activates the NF-кB2 signaling pathway (32). Given these characteristics of the receptors, the majority of this review will focus on BAFFR and it role in activating non-canonical NF- $\mathrm{B}$ signaling.

\section{BRIDGING THE GAP FROM RECEPTOR TO TRANSCRIPTION FACTOR}

An outline of NF- $\mathrm{B} 2$ signaling was given in the introduction, however a more in depth description of the proximal signaling events which lead to the activation of NF- $\kappa \mathrm{B} 2$ transcription programs in response to BAFF/BAFFR ligation is given below (Figure 1). These events have been recently elucidated using mainly in vitro systems employing on both CD40 and BAFFR as the activating receptors. A more complete understanding of the molecular events facilitating NF- $\kappa \mathrm{B} 2$ activation in response to BAFFR ligation will aid in understanding how the molecules involved have been manipulated in vivo in order to reveal the tissue specific outcomes of BAFF/BAFFR-mediated NF-кB2, which will be discussed in Section "Tissue Responses and Effector Functions: The Outcomes of NF-кB2 Signaling in Response to BAFF."

\section{THE ABSENCE OF BAFFR LIGATION: KEEPING NF- $K$ B2 SWITCHED OFF}

In contrast to many other signaling pathways, the initiation of NF$\kappa \mathrm{B} 2$ signaling by BAFFR actually results from the de-repression of the pathway, rather than its activation. The key kinase in the pathway, NF- $\kappa \mathrm{B}$ inducing kinase (NIK) is constitutively degraded by the proteasome in the absence on BAFFR ligation (33). A complex consisting of TRAF2, TRAF3 and the cellular inducer of apoptosis proteins 1 or $2(\mathrm{cIAP} 1 / 2)$ is responsible for this degradation. While all three components of the complex have ubiquitin ligase capability, only the cIAPs have been shown to mediate the attachment of K48 ubiquitin linkages, which direct proteins to the proteasome for degradation $(34,35)$. Both TRAF2 and TRAF3 harbor RING domains in their $\mathrm{N}$ termini, however their ubiquitin ligase activity is thought to be restricted to K63 ubiquitin linkages which are involved in signaling interactions rather than degradation of proteins $(36,37)$. Thus the role of TRAF2 and TRAF3 is thought to be acting as a molecular bridge. TRAF3 is able to directly interact 

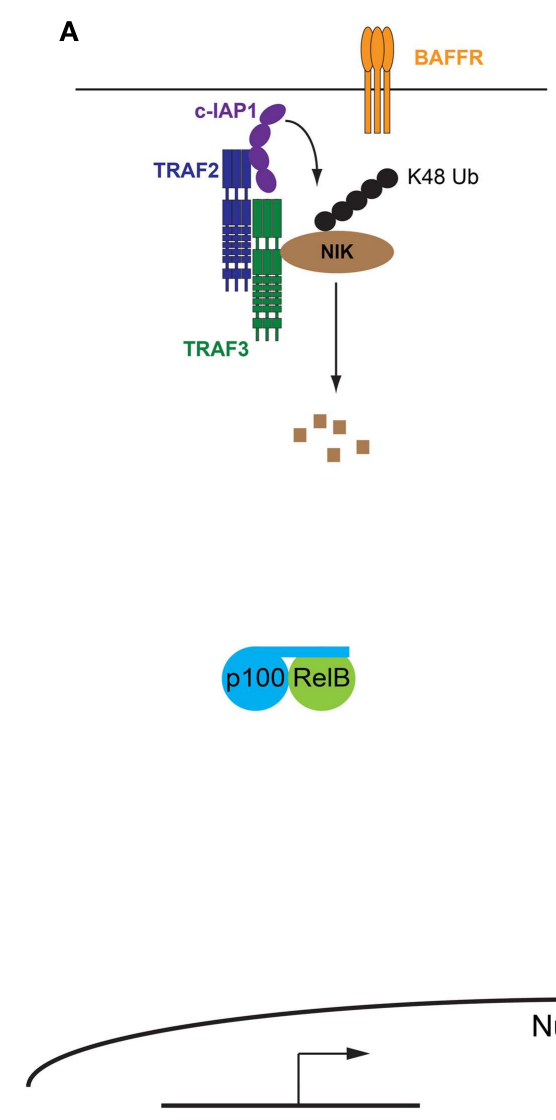

FIGURE 1 |The molecular details of BAFF/BAFFR-mediated activation of NF- $\mathrm{kB2}$ signaling pathway. (A) In the absence of BAFF a complex consisting of TRAF2, TRAF3, and cIAP1/2 facilitate the degradation of NIK, the key kinase involved in activation of NF-kB2 signaling. p100 inhibits NF-KB2 activation by sequestering RelB in the cytoplasm. (B) Following BAFF ligation of BAFFR, TRAF3 is recruited to the receptor and subsequently degraded by the combined actions of TRAF2 and clAP1/2. Lack of TRAF3 deactivates the TRAF/CIAP complex, releasing NIK from degradation and allowing it to accumulate in the cell. NIK then facilitates degradation of $\mathrm{p} 100$ via direct phosphorylation and phosphorylation of with NIK and it has long been recognized that this interaction is followed by the ubiquitylation and subsequent degradation of NIK (33). The interaction between TRAF2 and cIAP1/2 was more recently demonstrated to be essential for K48 ubiquitylation of NIK and the cIAP proteins were identified as the ubiquitin ligases responsible $(38,39)$. Interaction between TRAF2 and TRAF3 is the final step that brings the ubiquitin ligase, cIAP $1 / 2$ into close proximity with its target, NIK $(40,41)$. Indeed a fusion protein consisting of the RING and zinc finger domains of TRAF2 and the TRAF domain of TRAF3 was able to compensate for both TRAF2 and TRAF3 in the ubiquitin ligase complex and, along with cIAP1/2, facilitate the degradation of NIK (41).
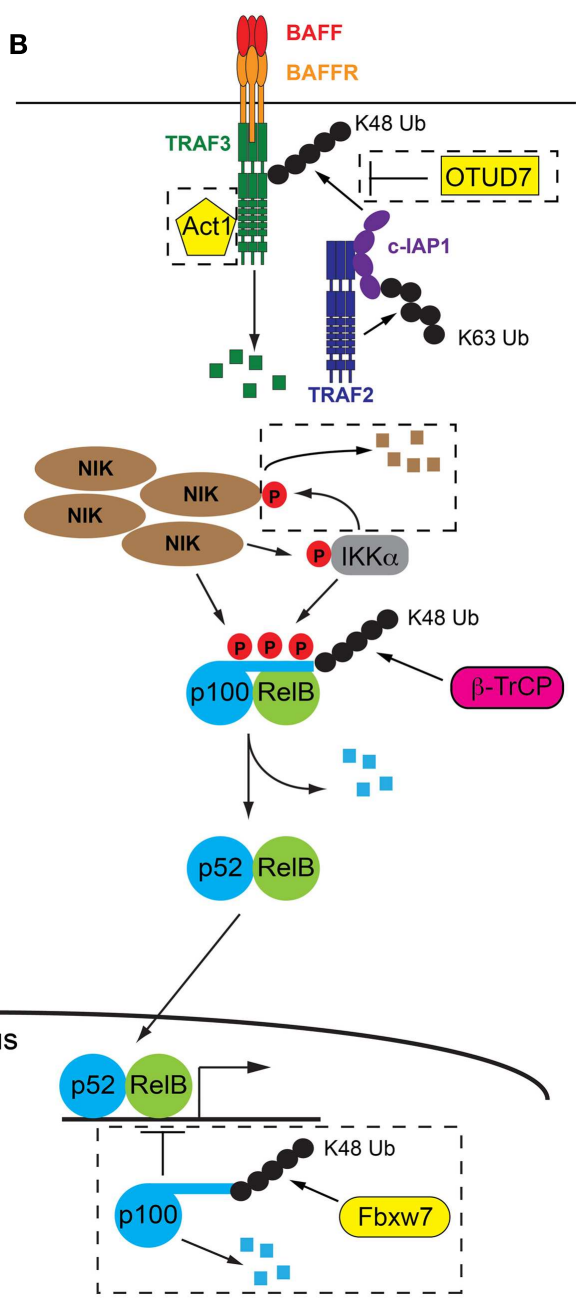

IKK $\alpha$. p100 is subsequently partially degraded and active p52/RelB dimers are able to migrate to the nucleus and initiate NF-kB2 specific gene transcription programs. Refer to Sections "The Absence of BAFFR Ligation: Keeping NF-kB2 Switched Off" and "Turning NF-KB2 on in Response to BAFFR Ligation" of text for further details. Negative control mechanisms which impact on NF-KB2 activation are indicated within dashed boxed, including OTUD7, Act1, IKK $\alpha$, and nuclear p100, refer to Section "Negative Control Mechanisms Limiting BAFFR Induced NF-kB2" of the text for further details. Small black circles represent ubiquitin, small red circles with $\mathrm{P}$ are phosphorylations.

\section{TURNING NF-KB2 ON IN RESPONSE TO BAFFR LIGATION}

The extracellular interaction between BAFF and BAFFR facilitates the recruitment of TRAF3 to the cytoplasmic domain of BAFFR, via a PVPAT binding site (32) which is unable to recruit other TRAF family members (42). Following recruitment to BAFFR, TRAF3 undergoes proteasomal degradation (33), a process which requires TRAF2 and cIAP1/2. Indeed cell line studies using CD40 engagement as a stimulus indicated that the K63 ubiquitylation of cIAP $1 / 2$ by TRAF2 contributed to enhanced activity of the cIAP's own ubiquitylation action. The target of cIAP1/2's K48 ubiquitylation action was TRAF3, resulting in its degradation by the proteasome (40). No direct interaction between cIAP1/2 
and TRAF3 has ever been shown, which suggests that TRAF2 plays a dual role in this process: it both recruits the ubiquitin ligase, cIAP1/2 to its target, TRAF3 via direct interaction with both proteins, as well as activating cIAP1/2, by K63 ubiquitylation, which optimizes the subsequent K48 ubiquitylation and degradation of TRAF3. It is likely a similar process occurs at the BAFFR and this is supported by in vivo evidence showing that TRAF3 is not efficiently degraded in TRAF2-deficient B cells, which express BAFFR and are subject to continual BAFFR ligation (43). It is not currently understood how the K63 polyubiquitination of cIAP $1 / 2$ promotes its own K48 ubiquitylation activity. It is tempting to speculate that this molecular mark on cIAP1/2 may contribute to directing its activity away from NIK and toward TRAF3. However it is equally possible that this change in specificity is due to conformational changes in TRAF3 caused by binding to BAFFR (42) or even the subcellular location of the event, that is proximal to BAFFR and thus the cell membrane. It is equally possible that $\mathrm{K} 63$ ubiquitination of cIAP1/2 results in the subsequent recruitment of another protein that acts to modulate the specificity of cIAP1/2, however as yet no such protein has been identified.

The recruitment to BAFFR and subsequent degradation of TRAF3 disrupts the cytoplasmic complex of TRAF2/TRAF3/ cIAP1/2, not only by the removal of TRAF3, but also by the recruitment of TRAF2 and CIAP1/2 to the vicinity of the BAFFR in order to mediate the degradation of TRAF3. These events mean that NIK is no longer targeted for constitutive degradation and subsequently accumulates within the cell. The requirement for NIK accumulation explains the slower kinetics of the non-canonical NF- $\kappa \mathrm{B}$ pathway compared to canonical NF- $\mathrm{B}$ signaling (44) and is thought to result in the phosphorylation of NIK, possibly via autophosphorylation (45). Recent evidence suggests that this phosphorylation of NIK is not necessary for its activity as the kinase domain is in the active conformation even in the absence of phosphorylation (46). Thus it appears that it is the rescue of NIK from degradation and its subsequent accumulation in the cell that is the critical step in activating NF-кB2 signaling. NIK is capable of both phosphorylating p100 directly, at serines 866 and 870 (3), as well as phosphorylating another p100 kinase, IKK $\alpha$ (47). IKK $\alpha$ phosphorylates p100 at serine 822 (1) and it is thought that the combination of all three p100 phosphorylations is required to initiate the processing of p100 to p52 $(48,49)$. This final processing step is mediated by beta-transducin repeat containing protein $(\beta-\operatorname{TrCP})$, a component of the SCF (Skp1-Cullin-1/Cdc53-F box protein) ubiquitin ligase complex (50). Active p52/RelB dimers are then free to migrate to the nucleus to initiate gene transcription programs (Figure 1).

A number of other positive mediators of NF- $\kappa$ B2 signaling have recently been identified whose contribution is not well understood. While the BAFFR cytoplasmic domain appears to contain only one TRAF binding site, specific for TRAF3, recent in vitro evidence suggests that it may also interact with TRAF1 (51). The presence of TRAF1 was demonstrated to decrease TRAF3, stabilize NIK, and increase p100 processing, though these functions were not a result of competing with TRAF3 for receptor binding. More recently TRAF1 has been shown to form heterotrimers with TRAF2, which display enhanced interaction with cIAP2 over the TRAF2 homotrimers (52). Thus TRAF1 may contribute to NF-кB2 activation by helping TRAF2 to enhance cIAP-mediated TRAF3 degradation. A further alternative is that TRAF1 may directly interact with NIK, stabilizing it and interfering with its TRAF2/TRAF3/cIAP1/2-mediated degradation, though the study suggesting this mechanism used $\mathrm{TNF} \alpha$ as a stimulus, presumably acting through its non-death domain receptor TNFR2 (53).

It has been suggested that Mucosal associated lymphoid tissue lymphoma translocation gene 1 (MALT1) is required for p100 phosphorylation, optimal p100 processing and p52/RelB nuclear translocation (54). MALT1 was shown to interact with TRAF3 and was therefore proposed to act as a scaffold for the TRAF/cIAP complex. However, molecular evidence for this is currently lacking. Interestingly the MALT1 binding partner B cell CLL/lymphoma 10 (Bcl10) has also been implicated both directly (55) (though through LPS stimulation, rather than BAFF stimulation) and indirectly $(56,57)$ to contribute to NF- $\kappa \mathrm{B} 2$ signaling. Whether these contributions also require MALT1 is largely unknown and requires further investigation.

\section{NEGATIVE CONTROL MECHANISMS LIMITING BAFFR INDUCED NF-кB2}

A number of mechanisms have been identified which target various components of this pathway as a way of limiting ongoing NF-кB2 signaling (Figure 1).

A further layer of control exists with respect to NF-кB2 or p100 itself: the presence of nuclear p100, which inhibits RelB binding to DNA. The ubiquitylation and subsequent degradation of nuclear p100 has recently been shown to be mediated by a different subunit of the SCF ubiquitin ligase complex, F box/WDF-repeat containing protein 7 (Fbxw7) and is thought to be constitutive $(58,59)$. Thus mechanisms affecting the function of Fbxw7 may impact on the efficiency of NF-кB2 activation.

Recently the deubiquitinating enzyme (DUB) ovarian tumor domain containing 7B (OTUD7B, also known as Cezanne) has been identified as the DUB responsible for removing degradative K48 ubiquitin chains from TRAF3 (60). OTUD7B was shown to be indirectly recruited to the receptor along with the TRAF3, TRAF2, and cIAP proteins in response to receptor ligation. Thus it is proposed to provide a negative feedback loop to oppose signal-induced activation of NF- $\mathrm{B} 2$.

TRAF3 interacting protein 2 (TRAF3IP2, also known as Act1) is recruited to BAFFR, via its interaction with TRAF3. Mice lacking TRAF3IP2 exhibit B cell hyperplasia (61), suggesting that TRAF3IP2 is a negative regulator of B cell survival possibly via modulation of NF- $\kappa$ B2 signaling (see next section for a description of the contribution of NF- $\kappa \mathrm{B} 2$ to B cell survival). However its mechanism of action is currently not understood and whether it exhibits its function independently of BAFFR ligation or in response to it, is unknown. The $\mathrm{B}$ cell hyperplasia phenotype is partially B cell extrinsic as B cell specific deletion of TRAF3IP2 produces a milder phenotype (61).

NF- $\kappa \mathrm{B}$ inducing kinase is also subject to negative feedback control in response to receptor ligation, which was independent of the TRAF/cIAP complex. NIK can be phosphorylated by IKK $\alpha$ which results in its destabilization and subsequent degradation by the proteasome. Whether this involved ubiquitylation and which ligase was involved has not be determined (62). 
TISSUE RESPONSES AND EFFECTOR FUNCTIONS: THE OUTCOMES OF NF- $\kappa$ B2 SIGNALING IN RESPONSE TO BAFF

Many of the studies investigating the role of TRAFs and cIAPs in $\mathrm{NF}-\kappa \mathrm{B} 2$ activation were performed in vitro using cell lines, MEFs and in some cases utilized synthetic antagonists. These studies in many cases and did not examine BAFFR-mediated NF- $\kappa$ B2 activation, but rather utilized a variety of other TNFRs including CD40 and LT- $\beta \mathrm{R}$ in order to study NF- $\kappa \mathrm{B} 2$ activation. Thus while these studies have allowed us to delineate the cytoplasmic events which contribute to NF- $\kappa \mathrm{B} 2$ activation, they have not contributed greatly to our knowledge of the physiological outcomes of NF- $\kappa$ B2 activation, especially downstream of BAFF/BAFFR ligation in primary $\mathrm{B}$ cells. Importantly in vivo work has provided much greater insight in this respect, in addition to supporting much of the mechanistic data obtained in vitro.

Although the non-canonical NF- $\mathrm{B}$ pathway has been clearly linked to a number of physiological responses, in some cases the activating receptor/ligand pair has not been clearly identified. Given the restriction of the expression of BAFF receptors to the lymphoid compartment, it is unsurprising that most identified roles for BAFF are in lymphocytes. Indeed the largest body of evidence for the role of BAFF mediated NF- $\kappa$ B2 signaling is in relation to B cell biology, including peripheral B cell survival and maturation, the generation of antibody response and the maintenance of PCs, all of which are further discussed below (Figure 2). Interestingly, NF-кB2 signaling is also essential for the development and organization of secondary lymphoid organs such as spleen, lymph node and Peyer's patches [reviewed in Ref. (63)]. However these functions of NF-кB2 appear to be mediated entirely by LT- $\beta$ R signaling, and do not involve BAFF or its receptors and thus will not be further discussed here.

\section{PERIPHERAL B CELL SURVIVAL AND MATURATION}

$B$ cells, like all cells of the hematopoietic lineage develop from hematopoietic stem cells in the bone marrow. The defining feature of $\mathrm{B}$ cell development is the expression of a $\mathrm{B}$ cell receptor (BCR), composed of immunoglobulin heavy and light chains derived from $\mathrm{V}(\mathrm{D}) \mathrm{J}$ recombination, which combine to define the unique specificity of each BCR and also of the antibody that the $B$ cell will secrete should it eventually differentiate into a plasma cell. Pre-B cells in the bone marrow express only a recombined immunoglobulin heavy chain along with a pseudo-light chain. Final rearrangement of the light chain immunoglobulin genes and expression of a fully functional BCR is the defining feature of an immature B cell in the bone marrow which is then ready to egress into the periphery. In the periphery immature B cells have been further categorized into transitional subsets T1, T2, and T3. There is much controversy of the number of these subsets (some researchers defining two T2 subsets, a T2 follicular and T2 $\mathrm{MZ}$ ), their position in the schema of development and even their functionality (it is possible that the T3 population represent not a transitional subset of immature B cells, but rather an anergic population). So while the exact developmental pathways of immature $\mathrm{B}$ cells in the periphery are not well defined, their outcomes are. Two subsets of mature B cells can be found in the periphery: follicular B cells, found in the spleen, lymph nodes and circulating in the

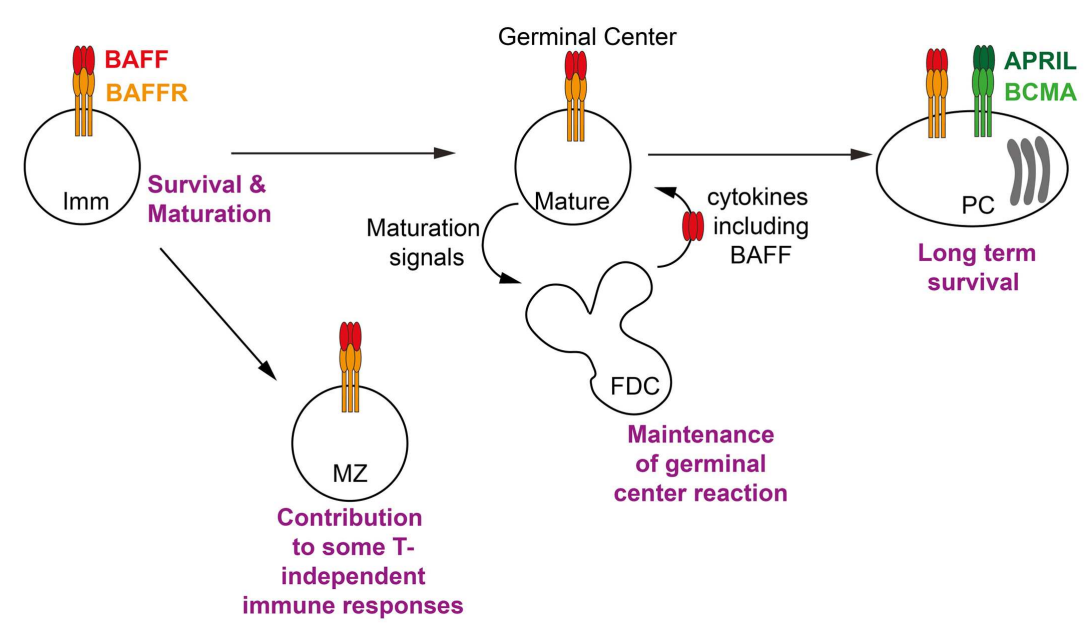

\begin{tabular}{|l|l|l|l|l|}
\hline Cell Type: & Immature & Marginal Zone & GC B cell & Plasma Cell \\
\hline $\begin{array}{l}\text { Outcome of } \\
\text { BAFF mediated } \\
\text { NF-кB2: }\end{array}$ & $\begin{array}{l}\text { survival } \\
\text { maturation }\end{array}$ & $\begin{array}{l}\text { contributes to } \\
\text { Tindependent } \\
\text { immune response }\end{array}$ & $\begin{array}{l}\text { maintenance } \\
\text { of GC reactions }\end{array}$ & long term survival \\
\hline
\end{tabular}

FIGURE 2 | Phenotypic outcomes of $B$ cells in response to BAFF/BAFFR-mediated NF- $\mathbf{k} \mathbf{B 2}$ activation. Activation of non-canonical NF-kB signaling in response to BAFF contributes to key events throughout the lifespan of a B cell. These include facilitating the survival of immature (Imm) B cells in the periphery and activating transcriptional programs which allow them to mature into follicular and marginal zone (MZ) B cells; contributing to some T-independent immune response; extending the duration of germinal center (GC) reactions; and maintaining long lived plasma cells (PCs) in the bone marrow. Refer to Section "Tissue Responses and Effector Functions: The Outcomes of NF-kB2 Signaling in Response to BAFF" of text for further details. 
blood, and MZ B cells, a sessile population found only in the spleen. The various genetically modified mice lines discussed below have demonstrated the importance of BAFF/BAFFR-mediated NF- $\kappa$ B2 signaling to the survival of mature peripheral $B$ cell subsets and their maturation (Figure 2). It should be noted that a further population of B cells exists, known as B1 B cells. These arise in the fetal liver and mainly populate the peritoneal cavity, though some are also found in the spleen. Their survival appears to be independent of BAFF and BAFFR signaling and thus they will not be further discussed here.

BAFF-deficient $(64,65)$ and BAFFR-deficient $(66,67)$ mice exhibit very similar phenotypes, with normal early B cell development in the bone marrow, but a paucity of peripheral B cell populations after transitional stage 1, suggesting that BAFF/BAFFR signaling is essential for $B$ cell maturation and survival in the periphery. In addition a naturally occurring mutant strain A/WySnJ, which lacks peripheral B cells, was identified to have a mutation in the Tnfrsf13c gene that encodes $\operatorname{BAFFR}(68,69)$ further validating the role of BAFF and BAFFR in supporting peripheral $B$ cell survival. In contrast, BAFF transgenic mice display expanded mature $\mathrm{B}$ cells in the periphery, demonstrating that the constitutive production of BAFF is limiting and restricts total B cell numbers in wild-type mice $(70,71)$. It was of course possible that signaling through the other BAFF receptors may contribute to $\mathrm{B}$ cell survival. However, the phenotype of BCMA- and TACIdeficient mice, demonstrate that BAFF/BAFFR signaling is the main contributor to this phenotype. BCMA-deficient mice do not display any B cell specific phenotype $(65,72)$ and TACI-deficient mice actually exhibit a slight hyperplasia of B cells, suggesting negative regulatory role for this receptor in maintaining $\mathrm{B}$ cell populations $(73,74)$.

The accumulation of B cells in BAFF transgenic mice is associated with autoantibody production and autoimmune manifestations $(70,71)$ suggesting that induced or increased production of BAFF may rescue some self-reactive B cells from elimination from the repertoire. This was verified to be the case using transgenic mouse models of B cell self-reactivity $(75,76)$ and may contribute to the onset of disease in a number of human autoimmune diseases associated with increased levels of circulating BAFF (21).

As described above, BAFF/BAFFR signaling efficiently activates the NF- $\kappa$ B2 pathway and genetic evidence also demonstrates that it is this pathway that primarily supports peripheral B cell survival. Thus NF-кB2-deficient mice also display a deficit in peripheral B cells $(77,78)$ and more importantly the survival ex vivo of those that do exist cannot be rescued by addition of BAFF, emphasizing that this pathway is required to facilitate BAFF's survival effect (79). The survival of some periphery B cells to maturity in NF- $\kappa$ B2-deficient mice suggests that other signaling pathways also contribute to $\mathrm{B}$ cell survival and maturation. Indeed NF$\kappa \mathrm{B} 1 / \mathrm{NF}-\kappa \mathrm{B} 2$ double-deficient mice show a more severe loss of peripheral B cells $(80)$ and certainly NF- $\kappa \mathrm{B} 1$ signaling activated by the BCR contributes to B cell survival. At least part of the canonical pathway's contribution is indirect, as p100 and RelB are NF- $\kappa \mathrm{B} 1$ regulated genes (81-83). Thus canonical activation may be required to furnish the cell with sufficient components of the non-canonical pathway to allow it to promote B cell survival (84). Over activation of the canonical pathway can substitute for loss of BAFFR (85). However, it is likely that under physiological conditions both pathways contribute to $B$ cell survival and that the BCR is the primary activator of canonical NF- $\mathrm{B}$ signaling, whilst $\mathrm{BAFFR}$ is primarily responsible for activating NF- $\kappa \mathrm{B} 2$ signaling.

$\mathrm{NF}-\kappa \mathrm{B}$ inducing kinase is the central kinase controlling NF- $\kappa \mathrm{B} 2$ activity. Deficiency of NIK (86) or mutation in its kinase domain (alymphoplasia - aly mice) (87) results in severe lymphoid abnormalities including loss of lymph nodes and Peyer's patches as well as B cell lymphopenia and splenic disorganization. As mentioned above control of lymphoid organ formation and organization has been attributed to LT- $\beta \mathrm{R}$ mediated NF- $\kappa \mathrm{B} 2$ signaling and indeed these mice phenocopy LT- $\beta$ R-deficient mice with respect to these phenotypes (88). These abnormalities are also more similar to NF- $\mathrm{B} 1 / \mathrm{NF}-\kappa \mathrm{B} 2$ double-deficient mice than either of the single deficient mice alone. Indeed it has been suggested that, in addition to its role in NF- $\mathrm{B} 2$ signaling, NIK may also contribute to NF$\kappa \mathrm{B} 1$ signaling. Despite the many additional phenotypes present in the aly mice, they retain the $\mathrm{B}$ cell lymphopenia common to mice models with defects in BAFF/BAFFR signaling and NF- $\kappa$ B2 signaling. Thus the phenotype of NIK-deficient mice also reflects the role of BAFFR-mediated NF- $\mathrm{B} 2$ activation in B cell survival and maturation.

In contrast to deletion of other components of the NF- $\kappa$ B2 pathway, deletion of IKK $\alpha$ results in perinatal lethality (89) suggesting that this kinase has additional roles outside NF- $\mathrm{B}$ signaling. Bone marrow chimeras for IKK $\alpha$-deficient fetal liver cells or mice expressing a kinase-inactive version of $\mathrm{IKK} \alpha$, do display $\mathrm{B}$ cell abnormalities similar to other mice models with defective NF- $\mathrm{B} 2$, including a deficit in peripheral B cell numbers and impaired GC formation $(90,91)$. However, given that non-NF- $\kappa$ B2 related roles for IKK $\alpha$ exist and may confound NF- $\kappa \mathrm{B} 2$ related phenotypes, further detailed description of these mice will not be undertaken here.

One outcome of NF- $\kappa \mathrm{B} 2$ signaling which is thought to promote $B$ cell survival is the upregulation of anti-apoptotic molecules such as B cell CLL/lymphoma 2 (Bcl-2) (92, 93). Indeed transgenic overexpression of Bcl-2 in mice models lacking functional BAFFR signaling was sufficient to restore mature B cell populations $(66,94$, 95). However while follicular B cells were observed in these models, MZ B cells were not restored. This demonstrated that in addition to providing survival signals to peripheral B cells, BAFF/BAFFR signaling is also essential for the complete maturation of $\mathrm{B}$ cells into $\mathrm{MZ}$ phenotype.

In line with this finding, mouse models with hyperactive NF$\kappa \mathrm{B} 2$ signaling display an expansion of the MZ B cell population, confirming that NF- $\kappa$ B2 signaling promotes this phenotypic outcome. These models include BAFF transgenic mice (71), as well as mice lacking components of the ubiquitin ligase complex which facilitates NIK degradation, namely TRAF2, TRAF3, or the cIAPs (43, 96-98). TRAF2 and TRAF3 play co-operative, but distinct roles in facilitating both the constitutive suppression of NF- $\kappa$ B2 signaling and the BAFFR-mediated activation of this pathway, the molecular details of which are described above. Mice completely lacking either TRAF are perinatally lethal $(99,100)$. Thus the use of a B cell specific deletion system to investigate their role in $B$ cells has been important in furthering our understanding of these molecules. Lack of either TRAF2 or TRAF3 specifically in B cells 
led to increased NF-кB2 signaling and an enlarged mature B cell population, with the largest expansion being in the MZ compartment of the spleen (43). While loss of TRAF2 or TRAF3 from B cells produced a similar phenotype, the implication from in vitro work that the two molecules are not performing the same function in regulating BAFFR signaling is supported by evidence from in vivo work. Firstly, the fact that loss of either TRAF resulted in the same phenotype, that is one was not able to completely compensate for the loss of the other. Secondly, mice lacking both TRAF2 and TRAF3 from their B cells did not display a more extreme phenotype in terms of levels of NF-кB2 activation or expansion of mature B cell populations, as would be expected if TRAF2 and TRAF3 were able to partially compensate for each other (43).

In contrast to the TRAF proteins, cIAP1 and cIAP2 are able to compensate for each other in their roles in BAFFR signaling. Thus mice completely deficient in cIAP2 or mice lacking cIAP1 in $\mathrm{B}$ cells, both displayed normal NF- $\kappa \mathrm{B} 2$ activation in their B cells and consequently normal $B$ cell survival and maturation. However mice lacking both cIAP1 and cIAP2 from their B cells had hyperactive NF- $\kappa \mathrm{B} 2$ and expanded mature B cell populations (98). cIAP1/2-deficient B cells also contained high levels of TRAF3 (98). This demonstrated definitively that in vivo cIAP1 and cIAP2 are able to compensate for each other in facilitating both the degradation of NIK to suppress NF- $\kappa \mathrm{B} 2$ activation and the degradation of TRAF3 in order to activate it. Indeed the ubiquitin ligase activity of cIAPs was shown to be essential in vivo to mediate these processes by the development of mice in which cIAP2 contained mutations which inactivated its E3 ligase activity (101). These mice displayed increase peripheral B cells and expanded MZs in the spleen. The authors proposed that mutant cIAP2 also had the affect of inhibiting the association of CIAP1 with TRAF2 and thus with the ubiquitin ligase complex which regulates NIK, thus explaining why in this case cIAP1 was not able to compensate for cIAP2 as it is able to in the complete absence of cIAP2.

The loss of either BAFF (43), or BAFFR (98) can be completely compensated for in terms of B cell survival and maturation by disruption of the TRAF/cIAP ubiquitin ligase complex and thus constitutive hyperactivation of NF- $\mathrm{B} 2$. Whilst other evidence presented above shows that BAFF, BAFFR and NF-кB2 signaling are all able to individually contribute to B cell survival and maturation, it is these experiments which definitively demonstrate that activation of NF- $\mathrm{B} 2$ sufficiently compensates for loss of BAFF or BAFFR. That is the primary, perhaps even the exclusive purpose of BAFF/BAFFR signaling in B cells is the activation of NF- $\kappa$ B2 signaling and it is this pathway which facilitates the transcriptional effects required in order for $B$ cells to survive and mature in the periphery. However, because of the tight link between BAFF signaling and B cell survival, the specific genes that are upregulated by BAFF in B cells and their roles in B cell physiology have been difficult to verify and are not well understood.

\section{B CELL ANTIBODY RESPONSES}

The main function of $B$ cells is to protect the body from foreign invasion by the production of antibodies. A B cell encountering a foreign antigen that matches the specificity of its BCR can ultimately differentiate into a plasma cell, a specialized antibodyproducing factory capable of making large amounts of secreted antibodies. Most foreign antigens illicit a T cell dependent antibody response, in which activated B cells form GCs where they are able interact with cognate $\mathrm{T}$ follicular helper cells as well as receive survival signals from support cells such as follicular dendritic cells (FDC) in order to select cells with high affinity for the foreign antigen that have been generated by somatic hypermutation (SHM) of the immunoglobulin genes [reviewed in Ref. (102)]. Alternatively some antigens are able to illicit maximal responses from B cells even in the absence of $\mathrm{T}$ cells and germinal center formation that is they illicit $\mathrm{T}$ cell independent antibody responses. These antigens tend to be generic antigens, for example the repeating carbohydrate units which make up bacterial cell walls. BAFF/BAFFR signaling has been implicated in both these processes (Figure 2).

\section{The germinal center reaction}

Despite the severe restriction on the survival of peripheral $B$ cell in mice deficient for either BAFF or BAFFR, those remaining are able to form of relatively normal GCs in which SHM can occur (67, $103,104)$. Thus BAFF/BAFFR signaling activating NF- $\kappa$ B2 is not required for these processes. However it appears they do play a role in the maintenance of GCs as GCs in mice lacking BAFF/BAFFR signaling dissipate a few days after they form. Interestingly the reasons for the instability differed between the two models. A lack of BAFF meant the FDC reticulum, important for trapping and presenting immune complexes failed to mature, probably leading to a lack of stimulation being received by the $\mathrm{B}$ cells present in the GC and subsequent breakdown of the GC $(103,104)$. However the FDC reticulum was normal in A/WySnJ (BAFFR mutant) mice, and $B$ cells instead exhibited a proliferation defect after initial germinal center formation (103). The most obvious explanation for this discrepancy is that BAFF acts directly on FDCs to promote their maturity and does so through a receptor other than BAFFR. In addition BAFF acting through the BAFFR on B cells is also required for germinal center maintenance. However this explanation is unlikely as both TACI and BCMA-deficient mice (72, 73) display normal GC formation, and therefore were unlikely to be the receptors responsible for the failure of FDC maturation in BAFF-deficient mice. Whatever the precise roles of BAFF are in supporting GC persistence, the fact that activated FDCs are a rich source of BAFF (105) makes them the most likely source of the BAFF required to support the GC.

A second explanation is that the maturity of the $\mathrm{B}$ cells entering the GC may impact on FDC maturation as this process is known to require interaction with GC B cells and those lacking signals from BAFF may be too immature to provide these signals to the FDCs. Indeed some B cells in A/WySnJ are able to mature past the transitional stages in contrast to BAFF- or BAFFR-deficient mice (106), thus the greater maturity of the these cells may explain their ability to support maturation of the FDC reticulum, where the $\mathrm{B}$ cells from BAFF-deficient mice cannot. The increased maturity of $\mathrm{B}$ cells in $\mathrm{A} / \mathrm{WySnJ}$ mice may be due to the ability of the mutant BAFFR to retain some signaling, as only the last 8 amino acids of this mutant receptor have been replaced with an unrelated transposon sequence (69). An examination of GC formation in BAFFR-deficient mice would help to answer this question and indeed like BAFF-deficient and A/WySnJ mice GCs in BAFFRdeficient mice form, but fail to be maintained (67), However, 
whether this is due to lack of FDC maturation or a B cell proliferation defect has unfortunately not been investigated. The authors did suggest that the defect they observed in BAFFR-deficient mice was less severe than that observed in BAFF-deficient mice. If this is the case it does suggest that BCMA or TACI, while not playing any essential role in GC maintenance as indicated by the phenotypes of their respective knockout mice, may be able to compensate for some of the functions of BAFFR in its absence.

It is highly likely given the involvement of BAFFR and its

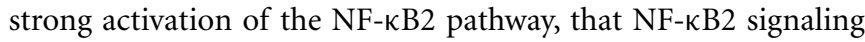
is involved in GC maintenance. However this has been difficult to confirm as NF-кB2-deficient mice completely fail to form GCs and FDC networks suggesting the NF- $\kappa \mathrm{B} 2$ is a key signaling pathway involved in the initiation of GCs as well as their maintenance $(77,78)$. Neither BAFF nor BAFFR are involved in initial GC formation, suggesting that in this case the NF- $\kappa \mathrm{B} 2$ pathway is being activated through a different ligand, possibly lymphotoxin $\alpha \beta$. Of course without formation of GC it is impossible to assess their maintenance. Adoptive transfer experiments in RelB-deficient mice showed that in order to restore GC formation, RelB was required in radioresistant stromal cells rather than hematopoietic cells (107). However, as GCs were only examined on day 10 postimmunization, it is impossible to say whether GC maintenance was also defective when RelB was absence from hematopoietic cells. In alymphoplasia (aly - NIK mutant) mice, similar adoptive transfer experiments revealed that functional NIK was indeed required in the stromal cells for FDC formation, but was also required in hematopoietic cells for GC formation (108). These apparently conflicting results as to the requirement for NF- $\mathrm{B} 2$ signaling in hematopoietic cells may be explained by functional redundancy of RelB with another member of the NF-кB family, whereas NIK, the central kinase of the NF- $\kappa \mathrm{B} 2$ pathway is absolutely required. While these results attempt to identify the cell types in which NF-кB2 signaling is required, it remains difficult to link its usage with the activating receptor, as indeed it is likely that more than one receptor contributes at various stages in GC formation and maintenance. Thus the questions surrounding GC maintenance remain.

Whilst normal NF- $\mathrm{B} 2$ appears necessary for GC formation, even hyperactive NF- $\mathrm{NB} 2$ cannot rescue GC formation in the absence of other signals required, for example $\mathrm{T}$ cell help in the form of CD40-CD40L interactions. The adapter molecules TRAF2, TRAF3, and cIAP1/2 are all involved in CD40 signaling in addition to their regulation of BAFFR signaling. While indeed they maintain their role as gatekeepers of NF- $\kappa \mathrm{B} 2$ signaling, almost certainly through analogous activation methods as BAFFR, they are also variously involved in the JNK, MAPK, and NF- $\mathrm{BB} 1$ pathways. Generally TRAF2 and cIAP1/2 are positive mediators of these pathways, whereas TRAF3 is a negative regulator $(40,98,109)$. Thus in mice lacking these molecules in their B cells, TRAF3deficient B cells are able to form and maintain GCs as they retain competent CD40 signaling, whereas GCs are stunted or almost completely absent in the TRAF2 and cIAP1/cIAP2-deficient mice, due to a lack of CD40 signaling, despite high NF-кB2 signaling (98). Likewise over expression of BAFF and thus NF-кB2 in BAFF transgenic mice is unable to rescue GC formation in CD40deficient mice (110). These results emphasize the complex nature of the signaling required in order to establish and maintain GC reactions. BAFF/BAFFR signaling contributes to these processes, but it is not a master regulator of them, as it is with B cell survival and maturation.

\section{T-independent antibody responses}

The involvement of both TACI and BAFF in T-independent antibody responses seems to be quite clear [reviewed in Ref. (111)]. It is possible that the multimeric BAFF $60 \mathrm{mer}$ is the ligand responsible for these functions (112). However, as TACI is not a strong inducer of NF-кB2 either via its interaction with BAFF or APRIL (84), it is unlikely that NF-кB2 signaling plays a role in these processes. For some T-independent antigens the BAFFR, and thus possibly NF$\kappa \mathrm{B} 2$ signaling, do appear to be involved. Antibody titers were lower in BAFFR-deficient mice compared to wild-type mice in response to NP-Ficoll or TNF-Ficoll but similar in response to Pneumovax vaccine $(66,67)$, suggesting that certain specific responses may require BAFFR signaling. In addition, some human patients with BAFFR deficiency also showed defects in mounting T-independent responses (113). However it remains unclear if BAFF/BAFFR signaling is directly required during a T-independent antibody response. It is possible that the defects observed in the absence of BAFFR, may be ascribed at least in part to a dramatic decrease in $\mathrm{MZ} B$ cells as this subset is recognized to be the origin of the early responders to T-independent antigens (114).

\section{PLASMA CELL MAINTENANCE}

Plasma cells are highly differentiated B cells capable of secreting large amounts of antibody and, along with the production of memory B cells, are the main B cell outcome of an immune response. Whilst large numbers of antigen specific PCs exist during and immediately following an immune response, over time these numbers greatly reduce. However, it is thought that a small number of the PCs resulting from a particular immune response survive long term and are the source of "basal" immunoglobulin found circulating within the body. The bone marrow has been identified as a survival niche for these long lived PCs and a variety of cells including stromal cells, myeloid cells and granulocytes all contribute to the production of factors which attract and promote the survival of PCs in these sites [reviewed in Ref. (115)]. Among these survival factors are APRIL and BAFF. Neutralization of both ligands is required in order to ablate plasma cell survival in the bone marrow $(19,116)$, however it is likely that under physiological conditions APRIL plays a greater role than BAFF. This is supported by the findings that APRIL is better than BAFF at supporting plasma cell survival in vitro (117) and in vivo plasma cell survival in APRIL-deficient mice was greatly diminished, whereas it was normal in BAFF-deficient mice $(117,118)$. BCMA is the receptor which is most thought to contribute to plasma cell survival, with BCMA-deficient mice failing to sustain long lived PCs in the bone marrow (119). It is possible, however, that TACI and/or BAFFR may contribute to these responses.

Although BCMA is not thought to be a strong activator of NF- $\mathrm{B} 2$ signaling, there is evidence that NF- $\kappa \mathrm{B} 2$ signaling can contribute to plasma cell survival, at least in the disease state. Multiple myeloma is late stage B cell malignancy that arises from PCs in the bone marrow. Whilst the primary genetic lesions are immunoglobulin gene translocations and hyperdiploidy, a large number of 
secondary genetic mutations also characterize the progression of the disease and it is amongst these that the NF- $\kappa$ B pathways have been strongly implicated (120-122). Mutations that activate NF$\kappa \mathrm{B} 2$ signaling including inactivating mutation in TRAF2, TRAF3, CIAP1, and $C I A P 2$, as well as activating mutations or duplications of $N I K$ and $N F-\kappa B 2$ have been identified in patients with multiple myeloma. These mutations are thought to contribute to the ability of the tumor to become independent in terms of its survival from the bone marrow microenvironment, that is no longer requiring BAFF and APRIL and other survival factors produced in the bone marrow. This in turn implies that NF- $\kappa$ B2 signaling is either normally involved in these processes for non-malignant PCs, or at least it can compensate for the signaling pathways involved under non-cancerous conditions. Thus it seems that BAFF induced NF$\kappa \mathrm{B} 2$ signaling plays a role at almost every stage of a B cell's life (Figure 2).

\section{CONCLUSION}

In addition to multiple myeloma, BAFF signaling as been implicated in a variety of autoimmune disorders, B cell malignancies and immunodeficiency disorders. It is also emerging that BAFF plays a role in regulating immune responses to infections [reviewed in Ref. (123)]. While in many of these cases there is quite strong evidence that BAFF contributes to disease, further molecular details, such as whether BAFFR is the responsible receptor and whether activation of NF- $\kappa \mathrm{B} 2$ also contributes to disease, require additional investigation. Given the central role of BAFF mediated NF- $\kappa$ B2 activation in the life span of B cells and the importance of B cells in attempting to control (in the case of infection) or potentially contributing to (in the case of autoimmunity) disease, it is likely that this signaling pathway indeed impacts greatly on our state of health and disease.

\section{ACKNOWLEDGMENTS}

Sandra Gardam and Robert Brink are supported by personal Research Fellowships from the National Health and Medical Research Council of Australia.

\section{REFERENCES}

1. Senftleben U, Cao Y, Xiao G, Greten FR, Krahn G, Bonizzi G, et al. Activation by IKKalpha of a second, evolutionary conserved, NF-kappa B signaling pathway. Science (2001) 293:1495-9. doi:10.1126/science.1062677

2. Hayden MS, Ghosh S. Shared principles in NF-kappaB signaling. Cell (2008) 132:344-62. doi:10.1016/j.cell.2008.01.020

3. Xiao G, Harhaj EW, Sun SC. NF-kappaB-inducing kinase regulates the processing of NF-kappaB2 p100. Mol Cell (2001) 7:401-9. doi:10.1016/S10972765(01)00187-3

4. Razani B, Reichardt AD, Cheng G. Non-canonical NF-kappaB signaling activation and regulation: principles and perspectives. Immunol Rev (2011) 244:44-54. doi:10.1111/j.1600-065X.2011.01059.x

5. Hauer J, Puschner S, Ramakrishnan P, Simon U, Bongers M, Federle C, et al. TNF receptor (TNFR)-associated factor (TRAF) 3 serves as an inhibitor of TRAF2/5-mediated activation of the noncanonical NF-kappaB pathway by TRAF-binding TNFRs. Proc Natl Acad Sci U S A (2005) 102:2874-9. doi:10.1073/pnas.0500187102

6. Gross JA, Johnston J, Mudri S, Enselman R, Dillon SR, Madden K, et al. TACI and BCMA are receptors for a TNF homologue implicated in B-cell autoimmune disease. Nature (2000) 404:995-9. doi:10.1038/35010115

7. Mukhopadhyay A, Ni J, Zhai Y, Yu GL, Aggarwal BB. Identification and characterization of a novel cytokine, THANK, a TNF homologue that activates apoptosis, nuclear factor-kappaB, and c-Jun NH2-terminal kinase. J Biol Chem (1999) 274:15978-81. doi:10.1074/jbc.274.23.15978

8. Schneider P, MacKay F, Steiner V, Hofmann K, Bodmer JL, Holler N, et al. BAFF, a novel ligand of the tumor necrosis factor family, stimulates B cell growth. J Exp Med (1999) 189:1747-56. doi:10.1084/jem.189.11.1747

9. Shu HB, Hu WH, Johnson H. TALL-1 is a novel member of the TNF family that is down-regulated by mitogens. J Leukoc Biol (1999) 65:680-3.

10. Moore PA, Belvedere O, Orr A, Pieri K, LaFleur DW, Feng P, et al. BLyS: member of the tumor necrosis factor family and B lymphocyte stimulator. Science (1999) 285:260-3. doi:10.1126/science.285.5425.260

11. Liu Y, Hong X, Kappler J, Jiang L, Zhang R, Xu L, et al. Ligand-receptor binding revealed by the TNF family member TALL-1. Nature (2003) 423:49-56. doi:10.1038/nature01543

12. Liu Y, Xu L, Opalka N, Kappler J, Shu HB, Zhang G. Crystal structure of sTALL1 reveals a virus-like assembly of TNF family ligands. Cell (2002) 108:383-94. doi:10.1016/S0092-8674(02)00631-1

13. Gavin AL, Ait-Azzouzene D, Ware CF, Nemazee D. DeltaBAFF, an alternate splice isoform that regulates receptor binding and biopresentation of the $\mathrm{B}$ cell survival cytokine, BAFF. J Biol Chem (2003) 278:38220-8. doi:10.1074/jbc. M306852200

14. Gavin AL, Duong B, Skog P, Ait-Azzouzene D, Greaves DR, Scott ML, et al. deltaBAFF, a splice isoform of BAFF, opposes full-length BAFF activity in vivo in transgenic mouse models. J Immunol (2005) 175:319-28.

15. Lopez-Fraga M, Fernandez R, Albar JP, Hahne M. Biologically active APRIL is secreted following intracellular processing in the Golgi apparatus by furin convertase. EMBO Rep (2001) 2:945-51. doi:10.1093/embo-reports/kve198

16. Pradet-Balade B, Medema JP, Lopez-Fraga M, Lozano JC, Kolfschoten GM, Picard A, et al. An endogenous hybrid mRNA encodes TWE-PRIL, a functional cell surface TWEAK-APRIL fusion protein. EMBO J (2002) 21:5711-20. doi:10.1093/emboj/cdf565

17. Huard B, McKee T, Bosshard C, Durual S, Matthes T, Myit S, et al. APRIL secreted by neutrophils binds to heparan sulfate proteoglycans to create plasma cell niches in human mucosa. J Clin Invest (2008) 118:2887-95. doi:10.1172/JCI33760

18. Kimberley FC, van Bostelen L, Cameron K, Hardenberg G, Marquart JA, Hahne $\mathrm{M}$, et al. The proteoglycan (heparan sulfate proteoglycan) binding domain of APRIL serves as a platform for ligand multimerization and cross-linking. FASEB J (2009) 23:1584-95. doi:10.1096/fj.08-124669

19. Ingold K, Zumsteg A, Tardivel A, Huard B, Steiner QG, Cachero TG, et al. Identification of proteoglycans as the APRIL-specific binding partners. J Exp Med (2005) 201:1375-83. doi:10.1084/jem.20042309

20. Roschke V, Sosnovtseva S, Ward CD, Hong JS, Smith R, Albert V, et al. BLyS and APRIL form biologically active heterotrimers that are expressed in patients with systemic immune-based rheumatic diseases. J Immunol (2002) 169:4314-21.

21. Mackay F, Schneider P. Cracking the BAFF code. Nature reviews. Immunology (2009) 9:491-502. doi:10.1038/nri2572

22. Bossen C, Ingold K, Tardivel A, Bodmer JL, Gaide O, Hertig S, et al. Interactions of tumor necrosis factor (TNF) and TNF receptor family members in the mouse and human. J Biol Chem (2006) 281:13964-71. doi:10.1074/jbc.M601553200

23. Wang R, Wang R, Ma N, Guo Y, Xiao H, Chen G, et al. Identify the key amino acid of BAFF binding with TACI. Cell Immunol (2013) 284:84-90. doi:10.1016/j.cellimm.2013.06.003

24. Ng LG, Sutherland AP, Newton R, Qian F, Cachero TG, Scott ML, et al. B cellactivating factor belonging to the TNF family (BAFF)- $R$ is the principal BAFF receptor facilitating BAFF costimulation of circulating $T$ and B cells. J Immunol (2004) 173:807-17.

25. Darce JR, Arendt BK, Wu X, Jelinek DF. Regulated expression of BAFF-binding receptors during human $B$ cell differentiation. J Immunol (2007) 179:7276-86,

26. Ye Q, Wang L, Wells AD, Tao R, Han R, Davidson A, et al. BAFF binding to T cell-expressed BAFF-R costimulates T cell proliferation and alloresponses. Eur J Immunol (2004) 34:2750-9. doi:10.1002/eji.200425198

27. Chang SK, Mihalcik SA, Jelinek DF. B lymphocyte stimulator regulates adaptive immune responses by directly promoting dendritic cell maturation. J Immunol (2008) 180:7394-403.

28. Chang SK, Arendt BK, Darce JR, Wu X, Jelinek DF. A role for BLyS in the activation of innate immune cells. Blood (2006) 108:2687-94. doi:10.1182/blood2005-12-017319 
29. Xia XZ, Treanor J, Senaldi G, Khare SD, Boone T, Kelley M, et al. TACI is a TRAF-interacting receptor for TALL-1, a tumor necrosis factor family member involved in B cell regulation. J Exp Med (2000) 192:137-43. doi:10.1084/jem.192.1.137

30. von Bulow GU, Bram RJ. NF-AT activation induced by a CAML-interacting member of the tumor necrosis factor receptor superfamily. Science (1997) 278:138-41. doi:10.1126/science.278.5335.138

31. Hatzoglou A, Roussel J, Bourgeade MF, Rogier E, Madry C, Inoue J, et al. TNF receptor family member BCMA (B cell maturation) associates with TNF receptor-associated factor (TRAF) 1, TRAF2, and TRAF3 and activates NFkappa B, elk-1, c-Jun N-terminal kinase, and p38 mitogen-activated protein kinase. J Immunol (2000) 165:1322-30.

32. Morrison MD, Reiley W, Zhang M, Sun SC. An atypical tumor necrosis factor (TNF) receptor-associated factor-binding motif of B cell-activating factor belonging to the TNF family (BAFF) receptor mediates induction of the noncanonical NF-kappaB signaling pathway. J Biol Chem (2005) 280:10018-24. doi:10.1074/jbc.M413634200

33. Liao G, Zhang M, Harhaj EW, Sun SC. Regulation of the NF-kappaB-inducing kinase by tumor necrosis factor receptor-associated factor 3-induced degradation. J Biol Chem (2004) 279:26243-50. doi:10.1074/jbc.M403286200

34. Bertrand MJ, Milutinovic S, Dickson KM, Ho WC, Boudreault A, Durkin J, et al. cIAP1 and cIAP2 facilitate cancer cell survival by functioning as E3 ligases that promote RIP1 ubiquitination. Mol Cell (2008) 30:689-700. doi:10.1016/j.molcel.2008.05.014

35. Blankenship JW, Varfolomeev E, Goncharov T, Fedorova AV, Kirkpatrick DS, Izrael-Tomasevic A, et al. Ubiquitin binding modulates IAP antagoniststimulated proteasomal degradation of c-IAP1 and c-IAP2(1). Biochem J (2009) 417:149-60. doi:10.1042/BJ20081885

36. Habelhah H, Takahashi S, Cho SG, Kadoya T, Watanabe T, Ronai Z. Ubiquitination and translocation of TRAF2 is required for activation of JNK but not of p38 or NF-kappaB. EMBO J (2004) 23:322-32. doi:10.1038/sj.emboj.7600044

37. Tseng PH, Matsuzawa A, Zhang W, Mino T, Vignali DA, Karin M. Different modes of ubiquitination of the adaptor TRAF3 selectively activate the expression of type I interferons and proinflammatory cytokines. Nat Immunol (2010) 11:70-5. doi:10.1038/ni.1819

38. Varfolomeev E, Blankenship JW, Wayson SM, Fedorova AV, Kayagaki N, Garg $\mathrm{P}$, et al. IAP antagonists induce autoubiquitination of c-IAPs, NF-kappaB activation, and TNFalpha-dependent apoptosis. Cell (2007) 131:669-81. doi:10. 1016/j.cell.2007.10.030

39. Vince JE, Wong WW, Khan N, Feltham R, Chau D, Ahmed AU, et al. , IAP antagonists target cIAP1 to induce TNFalpha-dependent apoptosis. Cell (2007) 131:682-93. doi:10.1016/j.cell.2007.10.037

40. Vallabhapurapu S, Matsuzawa A, Zhang W, Tseng PH, Keats JJ, Wang H, et al. Nonredundant and complementary functions of TRAF2 and TRAF3 in a ubiquitination cascade that activates NIK-dependent alternative NF-kappaB signaling. Nat Immunol (2008) 9:1364-70. doi:10.1038/ni.1678

41. Zarnegar BJ, Wang Y, Mahoney DJ, Dempsey PW, Cheung HH, He J, et al. Noncanonical NF-kappaB activation requires coordinated assembly of a regulatory complex of the adaptors cIAP1, cIAP2, TRAF2 and TRAF3 and the kinase NIK. Nat Immunol (2008) 9:1371-8. doi:10.1038/ni.1676

42. Ni CZ, Oganesyan G, Welsh K, Zhu X, Reed JC, Satterthwait AC, et al. Key molecular contacts promote recognition of the BAFF receptor by TNF receptor-associated factor 3: implications for intracellular signaling regulation. J Immunol (2004) 173:7394-400.

43. Gardam S, Sierro F, Basten A, Mackay F, Brink R. TRAF2 and TRAF3 signal adapters act cooperatively to control the maturation and survival signals delivered to B cells by the BAFF receptor. Immunity (2008) 28:391-401. doi:10.1016/j.immuni.2008.01.009

44. Saccani S, Pantano S, Natoli G. Modulation of NF-kappa B activity by exchange of dimers. Mol Cell (2003) 11:1563-74. doi:10.1016/S1097-2765(03)00227-2

45. Lin X, Mu Y, Cunningham ET Jr, Marcu KB, Geleziunas R, Greene WC. Molecular determinants of NF-kappaB-inducing kinase action. Mol Cell Biol (1998) 18:5899-907.

46. de Leon-Boenig G, Bowman KK, Feng JA, Crawford T, Everett C, Franke Y, et al. The crystal structure of the catalytic domain of the NF-kappaB inducing kinase reveals a narrow but flexible active site. Structure (2012) 20:1704-14. doi:10.1016/j.str.2012.07.013
47. Ling L, Cao Z, Goeddel DV. NF-kappaB-inducing kinase activates IKK-alpha by phosphorylation of Ser-176. Proc Natl Acad Sci U S A (1998) 95:3792-7. doi:10.1073/pnas.95.7.3792

48. Liang C, Zhang M, Sun SC. beta-TrCP binding and processing of NFkappaB2/p100 involve its phosphorylation at serines 866 and 870. Cell Signal (2006) 18:1309-17. doi:10.1016/j.cellsig.2005.10.011

49. Xiao G, Fong A, Sun SC. Induction of p100 processing by NF-kappaBinducing kinase involves docking IkappaB kinase alpha (IKKalpha) to p100 and IKKalpha-mediated phosphorylation. J Biol Chem (2004) 279:30099-105. doi:10.1074/jbc.M401428200

50. Fong A, Sun SC. Genetic evidence for the essential role of beta-transducin repeat-containing protein in the inducible processing of NF-kappa B2/p100. J Biol Chem (2002) 277:22111-4. doi:10.1074/jbc.C200151200

51. Lavorgna A, De Filippi R, Formisano S, Leonardi A. TNF receptor-associated factor 1 is a positive regulator of the NF-kappaB alternative pathway. Mol Immunol (2009) 46:3278-82. doi:10.1016/j.molimm.2009.07.029

52. Zheng C, Kabaleeswaran V, Wang Y, Cheng G, Wu H. Crystal structures of the TRAF2: CIAP2 and the TRAF1: TRAF2: cIAP2 complexes: affinity, specificity, and regulation. Mol Cell (2010) 38:101-13. doi:10.1016/j.molcel. 2010.03.009

53. Choudhary S, Kalita M, Fang L, Patel KV, Tian B, Zhao Y, et al. Inducible tumor necrosis factor (TNF) receptor-associated factor-1 expression couples the canonical to the non-canonical NF-kappaB pathway in TNF stimulation. J Biol Chem (2013) 288:14612-23. doi:10.1074/jbc.M113.464081

54. Tusche MW, Ward LA, Vu F, McCarthy D, Quintela-Fandino M, Ruland J, et al. Differential requirement of MALT1 for BAFF-induced outcomes in B cell subsets. J Exp Med (2009) 206:2671-83. doi:10.1084/jem.20091802

55. Bhattacharyya S, Borthakur A, Dudeja PK, Tobacman JK. Lipopolysaccharideinduced activation of NF-kappaB non-canonical pathway requires BCL10 serine 138 and NIK phosphorylations. Exp Cell Res (2010) 316:3317-27. doi:10.1016/j.yexcr.2010.05.004

56. Li Z, Wang H, Xue L, Shin DM, Roopenian D, Xu W, et al. Emu-BCL10 mice exhibit constitutive activation of both canonical and noncanonical NF-kappaB pathways generating marginal zone (MZ) B-cell expansion as a precursor to splenic MZ lymphoma. Blood (2009) 114:4158-68. doi:10.1182/blood-200812-192583

57. Yu M, Chen Y, He Y, Podd A, Fu G, Wright JA, et al. Critical role of B cell lymphoma 10 in BAFF-regulated NF-kappaB activation and survival of anergic B cells. J Immunol (2012) 189:5185-93. doi:10.4049/jimmunol.1102952

58. Busino L, Millman SE, Scotto L, Kyratsous CA, Basrur V, O’Connor O, et al. Fbxw7alpha- and GSK3-mediated degradation of p100 is a pro-survival mechanism in multiple myeloma. Nat Cell Biol (2012) 14:375-85. doi:10.1038/ ncb2463

59. Fukushima H, Matsumoto A, Inuzuka H, Zhai B, Lau AW, Wan L, et al. SCF(Fbw7) modulates the NFkB signaling pathway by targeting NFkB2 for ubiquitination and destruction. Cell Rep (2012) 1:434-43. doi:10.1016/j.celrep. 2012.04.002

60. Hu H, Brittain GC, Chang JH, Puebla-Osorio N, Jin J, Zal A, et al. OTUD7B controls non-canonical NF-kappaB activation through deubiquitination of TRAF3. Nature (2013) 494:371-4. doi:10.1038/nature11831

61. Qian Y, Qin J, Cui G, Naramura M, Snow EC, Ware CF, et al. Act1, a negative regulator in CD40- and BAFF-mediated B cell survival. Immunity (2004) 21:575-87. doi:10.1016/j.immuni.2004.09.001

62. Razani B, Zarnegar B, Ytterberg AJ, Shiba T, Dempsey PW, Ware CF, et al. Negative feedback in noncanonical NF-kappaB signaling modulates NIK stability through IKKalpha-mediated phosphorylation. Sci Signal (2010) 3:ra41. doi:10.1126/scisignal.2000778

63. Sun SC. The noncanonical NF-kappaB pathway. Immunol Rev (2012) 246:125-40. doi:10.1111/j.1600-065X.2011.01088.x

64. Gross JA, Dillon SR, Mudri S, Johnston J, Littau A, Roque R, et al. TACI-Ig neutralizes molecules critical for B cell development and autoimmune disease. impaired B cell maturation in mice lacking BLyS. Immunity (2001) 15:289-302. doi:10.1016/S1074-7613(01)00183-2

65. Schiemann B, Gommerman JL, Vora K, Cachero TG, Shulga-Morskaya S, Dobles $\mathrm{M}$, et al. An essential role for BAFF in the normal development of B cells through a BCMA-independent pathway. Science (2001) 293:2111-4. doi:10.1126/science.1061964 
66. Sasaki Y, Casola S, Kutok JL, Rajewsky K, Schmidt-Supprian M. TNF family member B cell-activating factor (BAFF) receptor-dependent and -independent roles for BAFF in B cell physiology. J Immunol (2004) 173:2245-52.

67. Shulga-Morskaya S, Dobles M, Walsh ME, Ng LG, MacKay F, Rao SP, et al. B cell-activating factor belonging to the TNF family acts through separate receptors to support B cell survival and T cell-independent antibody formation. J Immunol (2004) 173:2331-41.

68. Thompson JS, Bixler SA, Qian F, Vora K, Scott ML, Cachero TG, et al. BAFF-R, a newly identified TNF receptor that specifically interacts with BAFF. Science (2001) 293:2108-11. doi:10.1126/science.1061965

69. Yan M, Brady JR, Chan B, Lee WP, Hsu B, Harless S, et al. Identification of a novel receptor for B lymphocyte stimulator that is mutated in a mouse strain with severe B cell deficiency. Curr Biol (2001) 11:1547-52. doi:10.1016/S0960-9822(01)00481-X

70. Khare SD, Sarosi I, Xia XZ, McCabe S, Miner K, Solovyev I, et al. Severe B cell hyperplasia and autoimmune disease in TALL-1 transgenic mice. Proc Nat Acad Sci U S A (2000) 97:3370-5. doi:10.1073/pnas.97.7.3370

71. Mackay F, Woodcock SA, Lawton P, Ambrose C, Baetscher M, Schneider P, et al. Mice transgenic for BAFF develop lymphocytic disorders along with autoimmune manifestations. J Exp Med (1999) 190:1697-710. doi:10.1084/jem.190. 11.1697

72. Xu S, Lam KP. B-cell maturation protein, which binds the tumor necrosis factor family members BAFF and APRIL, is dispensable for humoral immune responses. Mol Cell Biol (2001) 21:4067-74. doi:10.1128/MCB.21.12.40674074.2001

73. von Bulow GU, van Deursen JM, Bram RJ. Regulation of the T-independent humoral response by TACI. Immunity (2001) 14:573-82. doi:10.1016/S10747613(01)00130-3

74. Yan M, Wang H, Chan B, Roose-Girma M, Erickson S, Baker T, et al. Activation and accumulation of B cells in TACI-deficient mice. Nat Immunol (2001) 2:638-43. doi:10.1038/89790

75. Thien M, Phan TG, Gardam S, Amesbury M, Basten A, Mackay F, et al. Excess BAFF rescues self-reactive B cells from peripheral deletion and allows them to enter forbidden follicular and marginal zone niches. Immunity (2004) 20:785-98. doi:10.1016/j.immuni.2004.05.010

76. Lesley R, Xu Y, Kalled SL, Hess DM, Schwab SR, Shu HB, et al. Reduced competitiveness of autoantigen-engaged $\mathrm{B}$ cells due to increased dependence on BAFF. Immunity (2004) 20:441-53. doi:10.1016/S1074-7613(04)00079-2

77. Caamano JH, Rizzo CA, Durham SK, Barton DS, Raventos-Suarez C, Snapper CM, et al. Nuclear factor (NF)-kappa B2 (p100/p52) is required for normal splenic microarchitecture and B cell-mediated immune responses. J Exp Med (1998) 187:185-96. doi:10.1084/jem.187.2.185

78. Franzoso G, Carlson L, Poljak L, Shores EW, Epstein S, Leonardi A, et al. Mice deficient in nuclear factor (NF)-kappa B/p52 present with defects in humoral responses, germinal center reactions, and splenic microarchitecture. J Exp Med (1998) 187:147-59. doi:10.1084/jem.187.2.147

79. Claudio E, Brown K, Park S, Wang H, Siebenlist U. BAFF-induced NEMOindependent processing of NF-kappa B2 in maturing B cells. Nat Immunol (2002) 3:958-65. doi:10.1038/ni842

80. Franzoso G, Carlson L, Xing L, Poljak L, Shores EW, Brown KD, et al. Requirement for NF-kappaB in osteoclast and B-cell development. Genes Dev (1997) 11:3482-96. doi:10.1101/gad.11.24.3482

81. Bren GD, Solan NJ, Miyoshi H, Pennington KN, Pobst LJ, Paya CV. Transcription of the RelB gene is regulated by NF-kappaB. Oncogene (2001) 20:7722-33. doi:10.1038/sj.onc. 1204868

82. Derudder E, Dejardin E, Pritchard LL, Green DR, Korner M, Baud V. RelB/p50 dimers are differentially regulated by tumor necrosis factor-alpha and lymphotoxin-beta receptor activation: critical roles for p100. J Biol Chem (2003) 278:23278-84. doi:10.1074/jbc.M300106200

83. Yilmaz ZB, Weih DS, Sivakumar V, Weih F. RelB is required for Peyer's patch development: differential regulation of p52-RelB by lymphotoxin and TNF. EMBO J (2003) 22:121-30. doi:10.1093/emboj/cdg004

84. Stadanlick JE, Kaileh M, Karnell FG, Scholz JL, Miller JP, Quinn WJ III, et al. Tonic B cell antigen receptor signals supply an NF-kappaB substrate for prosurvival BLyS signaling. Nat Immunol (2008) 9:1379-87. doi:10.1038/ni. 1666

85. Sasaki Y, Derudder E, Hobeika E, Pelanda R, Reth M, Rajewsky K, et al. Canonical NF-kappaB activity, dispensable for B cell development, replaces
BAFF-receptor signals and promotes B cell proliferation upon activation. Immunity (2006) 24:729-39. doi:10.1016/j.immuni.2006.04.005

86. Yin L, Wu L, Wesche H, Arthur CD, White JM, Goeddel DV, et al. Defective lymphotoxin-beta receptor-induced NF-kappaB transcriptional activity in NIK-deficient mice. Science (2001) 291:2162-5. doi:10.1126/science.1058453

87. Shinkura R, Kitada K, Matsuda F, Tashiro K, Ikuta K, Suzuki M, et al. Alymphoplasia is caused by a point mutation in the mouse gene encoding Nf-kappa b-inducing kinase. Nat Genet (1999) 22:74-7. doi:10.1038/8780

88. Futterer A, Mink K, Luz A, Kosco-Vilbois MH, Pfeffer K. The lymphotoxin beta receptor controls organogenesis and affinity maturation in peripheral lymphoid tissues. Immunity (1998) 9:59-70. doi:10.1016/S1074-7613(00)80588-9

89. Takeda K, Takeuchi O, Tsujimura T, Itami S, Adachi O, Kawai T, et al. Limb and skin abnormalities in mice lacking IKKalpha. Science (1999) 284:313-6. doi:10.1126/science.284.5412.313

90. Kaisho T, Takeda K, Tsujimura T, Kawai T, Nomura F, Terada N, et al. IkappaB kinase alpha is essential for mature B cell development and function. J Exp Med (2001) 193:417-26. doi:10.1084/jem.193.4.417

91. Mills DM, Bonizzi G, Karin M, Rickert RC. Regulation of late B cell differentiation by intrinsic IKKalpha-dependent signals. Proc Natl Acad Sci U S A (2007) 104:6359-64. doi:10.1073/pnas.0700296104

92. Do RK, Hatada E, Lee H, Tourigny MR, Hilbert D, Chen-Kiang S. Attenuation of apoptosis underlies B lymphocyte stimulator enhancement of humoral immune response. J Exp Med (2000) 192:953-64. doi:10.1084/jem. 192.7.953

93. Batten M, Groom J, Cachero TG, Qian F, Schneider P, Tschopp J, et al. BAFF mediates survival of peripheral immature B lymphocytes. J Exp Med (2000) 192:1453-66. doi:10.1084/jem.192.10.1453

94. Tardivel A, Tinel A, Lens S, Steiner QG, Sauberli E, Wilson A, et al. The antiapoptotic factor Bcl-2 can functionally substitute for the B cell survival but not for the marginal zone B cell differentiation activity of BAFF. Eur J Immunol (2004) 34:509-18. doi:10.1002/eji.200324692

95. Rahman ZS, Manser T. B cells expressing Bcl-2 and a signaling-impaired BAFFspecific receptor fail to mature and are deficient in the formation of lymphoid follicles and germinal centers. J Immunol (2004) 173:6179-88.

96. Grech AP, Amesbury M, Chan T, Gardam S, Basten A, Brink R. TRAF2 differentially regulates the canonical and noncanonical pathways of NF-kappaB activation in mature B cells. Immunity (2004) 21:629-42. doi:10.1016/j.immuni. 2004.09.011

97. Xie P, Stunz LL, Larison KD, Yang B, Bishop GA. Tumor necrosis factor receptorassociated factor 3 is a critical regulator of B cell homeostasis in secondary lymphoid organs. Immunity (2007) 27:253-67. doi:10.1016/j.immuni.2007.07.012

98. Gardam S, Turner VM, Anderton H, Limaye S, Basten A, Koentgen F, et al. Deletion of cIAP1 and cIAP2 in murine B lymphocytes constitutively activates cell survival pathways and inactivates the germinal center response. Blood (2011) 117:4041-51. doi:10.1182/blood-2010-10-312793

99. Yeh WC, Shahinian A, Speiser D, Kraunus J, Billia F, Wakeham A, et al. Early lethality, functional NF-kappaB activation, and increased sensitivity to TNF-induced cell death in TRAF2-deficient mice. Immunity (1997) 7:715-25. doi:10.1016/S1074-7613(00)80391-X

100. Xu Y, Cheng G, Baltimore D. Targeted disruption of TRAF3 leads to postnatal lethality and defective T-dependent immune responses. Immunity (1996) 5:407-15. doi:10.1016/S1074-7613(00)80497-5

101. Conze DB, Zhao Y, Ashwell JD. Non-canonical NF-kappaB activation and abnormal B cell accumulation in mice expressing ubiquitin protein ligaseinactive c-IAP2. PLoS Biol (2010) 8:e1000518. doi:10.1371/journal.pbio. 1000518

102. Gatto D, Brink R. The germinal center reaction. J Allergy Clin Immunol (2010) 126:898-907. doi:10.1016/j.jaci.2010.09.007

103. Rahman ZS, Rao SP, Kalled SL, Manser T. Normal induction but attenuated progression of germinal center responses in BAFF and BAFF-R signaling-deficient mice. J Exp Med (2003) 198:1157-69. doi:10.1084/jem.20030495

104. Vora KA, Wang LC, Rao SP, Liu ZY, Majeau GR, Cutler AH, et al. Cutting edge: germinal centers formed in the absence of $\mathrm{B}$ cell-activating factor belonging to the TNF family exhibit impaired maturation and function. J Immunol (2003) 171:547-51.

105. El Shikh ME, El Sayed RM, Sukumar S, Szakal AK, Tew JG. Activation of B cells by antigens on follicular dendritic cells. Trends Immunol (2010) 31:205-11. doi:10.1016/j.it.2010.03.002 
106. Mayne CG, Nashold FE, Sasaki Y, Hayes CE. Altered BAFF-receptor signaling and additional modifier loci contribute to systemic autoimmunity in A/WySnJ mice. Eur J Immunol (2009) 39:589-99. doi:10.1002/eji.200838569

107. Weih DS, Yilmaz ZB, Weih F. Essential role of RelB in germinal center and marginal zone formation and proper expression of homing chemokines. J Immunol (2001) 167:1909-19.

108. Yamada T, Mitani T, Yorita K, Uchida D, Matsushima A, Iwamasa K, et al. Abnormal immune function of hemopoietic cells from alymphoplasia (aly) mice, a natural strain with mutant NF-kappa B-inducing kinase. J Immunol (2000) 165:804-12.

109. Matsuzawa A, Tseng PH, Vallabhapurapu S, Luo JL, Zhang W, Wang H, et al. Essential cytoplasmic translocation of a cytokine receptor-assembled signaling complex. Science (2008) 321:663-8. doi:10.1126/science.1157340

110. Enzler T, Bonizzi G, Silverman GJ, Otero DC, Widhopf GF, Anzelon-Mills A, et al. Alternative and classical NF-kappa B signaling retain autoreactive B cells in the splenic marginal zone and result in lupus-like disease. Immunity (2006) 25:403-15. doi:10.1016/j.immuni.2006.07.010

111. Mackay F, Schneider P. TACI, an enigmatic BAFF/APRIL receptor, with new unappreciated biochemical and biological properties. Cytokine Growth Factor Rev (2008) 19:263-76. doi:10.1016/j.cytogfr.2008.04.006

112. Bossen C, Cachero TG, Tardivel A, Ingold K, Willen L, Dobles M, et al. TACI, unlike BAFF-R, is solely activated by oligomeric BAFF and APRIL to support survival of activated B cells and plasmablasts. Blood (2008) 111:1004-12. doi:10.1182/blood-2007-09-110874

113. Warnatz K, Salzer U, Rizzi M, Fischer B, Gutenberger S, Bohm J, et al. B-cell activating factor receptor deficiency is associated with an adult-onset antibody deficiency syndrome in humans. Proc Natl Acad Sci U S A (2009) 106:13945-50. doi:10.1073/pnas.0903543106

114. Martin F, Oliver AM, Kearney JF. Marginal zone and B1 B cells unite in the early response against T-independent blood-borne particulate antigens. Immunity (2001) 14:617-29. doi:10.1016/S1074-7613(01)00129-7

115. Tangye SG. Staying alive: regulation of plasma cell survival. Trends Immunol (2011) 32:595-602. doi:10.1016/j.it.2011.09.001

116. Benson MJ, Dillon SR, Castigli E, Geha RS, Xu S, Lam KP, et al. Cutting edge: the dependence of plasma cells and independence of memory B cells on BAFF and APRIL. J Immunol (2008) 180:3655-9.

117. Belnoue E, Pihlgren M, McGaha TL, Tougne C, Rochat AF, Bossen C, et al. APRIL is critical for plasmablast survival in the bone marrow and poorly expressed by early-life bone marrow stromal cells. Blood (2008) 111:2755-64. doi:10.1182/blood-2007-09-110858
118. Matthes T, Dunand-Sauthier I, Santiago-Raber ML, Krause KH, Donze O, Passweg J, et al. Production of the plasma-cell survival factor a proliferationinducing ligand (APRIL) peaks in myeloid precursor cells from human bone marrow. Blood (2011) 118:1838-44. doi:10.1182/blood-2011-01-332940

119. O’Connor BP, Raman VS, Erickson LD, Cook WJ, Weaver LK, Ahonen C, et al. BCMA is essential for the survival of long-lived bone marrow plasma cells. J Exp Med (2004) 199:91-8. doi:10.1084/jem.20031330

120. Annunziata CM, Davis RE, Demchenko Y, Bellamy W, Gabrea A, Zhan F, et al. Frequent engagement of the classical and alternative NF-kappaB pathways by diverse genetic abnormalities in multiple myeloma. Cancer Cell (2007) 12:115-30. doi:10.1016/j.ccr.2007.07.004

121. Demchenko YN, Glebov OK, Zingone A, Keats JJ, Bergsagel PL, Kuehl WM. Classical and/or alternative NF-kappaB pathway activation in multiple myeloma. Blood (2010) 115:3541-52. doi:10.1182/blood-2009-09-243535

122. Keats JJ, Fonseca R, Chesi M, Schop R, Baker A, Chng WJ, et al. Promiscuous mutations activate the noncanonical NF-kappaB pathway in multiple myeloma. Cancer Cell (2007) 12:131-44. doi:10.1016/j.ccr.2007.07.003

123. Vincent FB, Saulep-Easton D, Figgett WA, Fairfax KA, Mackay F. The BAFF/APRIL system: emerging functions beyond B cell biology and autoimmunity. Cytokine Growth Factor Rev (2013) 24:203-15. doi:10.1016/j.cytogfr. 2013.04.003

Conflict of Interest Statement: The authors declare that the research was conducted in the absence of any commercial or financial relationships that could be construed as a potential conflict of interest.

Received: 01 November 2013; paper pending published: 02 December 2013; accepted: 24 December 2013; published online: 06 January 2014.

Citation: Gardam $S$ and Brink R (2014) Non-canonical NF- $\kappa$ B signaling initiated by BAFF influences B cell biology at multiple junctures. Front. Immunol. 4:509. doi: 10.3389/fimmu.2013.00509

This article was submitted to Inflammation, a section of the journal Frontiers in Immunology.

Copyright (c) 2014 Gardam and Brink. This is an open-access article distributed under the terms of the Creative Commons Attribution License (CC BY). The use, distribution or reproduction in other forums is permitted, provided the original author (s) or licensor are credited and that the original publication in this journal is cited, in accordance with accepted academic practice. No use, distribution or reproduction is permitted which does not comply with these terms. 